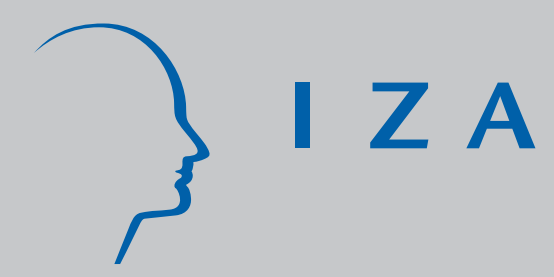

IZADP No. 1980

An Analysis of Reservation Wages for the Economically Inactive

David H. Blackaby

Philip D. Murphy

Peter J. Sloane

Paul L. Latreille

Nigel C. O'Leary

February 2006 


\title{
An Analysis of Reservation Wages for the Economically Inactive
}

\author{
David H. Blackaby \\ University of Wales Swansea \\ Paul L. Latreille \\ University of Wales Swansea \\ Philip D. Murphy \\ University of Wales Swansea \\ Nigel O'Leary \\ University of Wales Swansea \\ Peter J. Sloane \\ University of Wales Swansea and IZA Bonn
}

Discussion Paper No. 1980
February 2006

IZA

P.O. Box 7240

53072 Bonn

Germany

Phone: +49-228-3894-0

Fax: +49-228-3894-180

Email: iza@iza.org

\begin{abstract}
Any opinions expressed here are those of the author(s) and not those of the institute. Research disseminated by IZA may include views on policy, but the institute itself takes no institutional policy positions.

The Institute for the Study of Labor (IZA) in Bonn is a local and virtual international research center and a place of communication between science, politics and business. IZA is an independent nonprofit company supported by Deutsche Post World Net. The center is associated with the University of Bonn and offers a stimulating research environment through its research networks, research support, and visitors and doctoral programs. IZA engages in (i) original and internationally competitive research in all fields of labor economics, (ii) development of policy concepts, and (iii) dissemination of research results and concepts to the interested public.
\end{abstract}

IZA Discussion Papers often represent preliminary work and are circulated to encourage discussion. Citation of such a paper should account for its provisional character. A revised version may be available directly from the author. 
IZA Discussion Paper No. 1980

February 2006

\section{ABSTRACT}

\section{An Analysis of Reservation Wages for the Economically Inactive}

This paper uses unique data for the economically inactive to calculate elasticity estimates of the reservation wage and exit probability with respect to state benefits and the arrival rate of job offers, and finds that the inactive react in similar ways to benefit increases as the unemployed.

JEL Classification: J21, J22, J31

Keywords: economic inactivity, reservation wages

Corresponding author:

Phil Murphy

School of Business and Economics

University of Wales Swansea

Singleton Park

Swansea, SA2 8PP

United Kingdom

Email: p.d.murphy@swansea.ac.uk 


\section{Introduction}

Despite having an employment rate which is almost 5 percentage points above the 70 per cent target agreed by European member states at the Lisbon summit in 2000, the UK Government has recently set itself a target of achieving an 80 per cent employment rate by 2010 (see Department of Work and Pensions, 2005). With UK unemployment at a historically low level, the government has recognised that further improvements in the employment rate are unlikely to occur unless they are accompanied by reductions in the level of economic inactivity. As only eight of the then 15 member states of the European Union (EU15) in 2000 had participation rates equal to or better than the Lisbon target, meeting this policy goal has necessarily involved a shift in emphasis in Europe away from the problems associated with unemployment towards those associated with economic inactivity.

Interestingly, this shift in policy emphasis in both the UK and mainland Europe has coincided with a growing recognition that the boundary between unemployment and economic inactivity is less sharp today than it once was (see Schweitzer, 2003 for some UK evidence); yet very little is still known about the labour market aspirations of economically inactive persons. This paper attempts to redress this imbalance using a unique survey of the economically inactive in one region of the UK (Wales) to estimate search parameters of interest to policy makers (i.e. the elasticity of reservation wages and the exit probability with respect to state benefits and the arrival rate of job offers). We follow a method suggested by Lancaster and Chesher (1983) which deduces key search parameters without having to make arbitrary statistical assumptions about the nature of the offer wage distribution. To our knowledge this is the first time such an analysis has been undertaken for the economically inactive. While the focus is on only one region in the UK, given that it is currently and historically characterised by above average levels of economic inactivity the results are likely 
to be informative about other less adversely affected areas of the UK and, perhaps, other parts of Europe.

\section{Theoretical framework}

Mortensen (1986) has shown that the optimal reservation wage for a risk neutral individual in a stationary job search model satisfies:

$$
(\lambda / \rho) \int_{w^{\mathrm{r}}}\left(\mathrm{w}-\mathrm{w}^{\mathrm{r}}\right) \mathrm{dF}(\mathrm{w})=\mathrm{c}+\mathrm{w}^{\mathrm{r}}-\mathrm{b}
$$

where $\lambda$ is the arrival rate of job offers; $\rho$ is the discount rate; $\mathrm{w}^{\mathrm{r}}$ is the optimal reservation wage; $\mathrm{F}(\mathrm{w})$ is the wage offer distribution; $\mathrm{c}$ is the cost of search; and $\mathrm{b}$ non-employment benefits. Equation (1) simply states the optimal reservation wage is chosen so that the marginal benefits of search equal the marginal costs of search.

In a stationary model the probability of finding a job $(\theta)$, is simply the product of the job arrival probability and the probability of accepting a job offer. That is:

$$
\theta=\lambda\left[1-\mathrm{F}\left(\mathrm{w}^{\mathrm{r}}\right)\right]
$$

which is also the hazard rate.

Using this framework, Lancaster and Chesher (1983) have shown that several important structural parameters of a job search model can be deduced, rather than estimated, from information on reservation wages $\left(w^{r}\right)$, expected wages in employment $\left(x=E\left(w \mid w>w^{r}\right)\right)$ and state benefits (b). Specifically, the elasticity of the reservation wage with respect to benefits and the job arrival rate is (Lancaster and Chesher, 1983: p1666): 


$$
\begin{aligned}
& \frac{\partial \operatorname{Ln} w^{r}}{\partial \operatorname{Ln} b}=\frac{b}{w^{r}} \frac{1}{1+\theta / \rho}=\frac{b}{w^{r}} \frac{x-w^{r}}{x-b} \\
& \frac{\partial \operatorname{Ln} w^{r}}{\partial \operatorname{Ln} \lambda}=\frac{1}{w^{r}} \frac{w^{r}-b}{1+\theta / \rho}=\frac{w^{r}-b}{w^{r}} \frac{x-w^{r}}{x-b}
\end{aligned}
$$

To derive other parameters of interest to policy makers requires assumptions about the nature of the wage offer distribution $\mathrm{F}(\mathrm{w})$. While acknowledging that results are sensitive to this choice, Lancaster and Chesher choose to use the Pareto distribution. This gives the elasticity of the hazard rate with respect to benefits and the job arrival rate as:

$$
\begin{aligned}
& \frac{\partial \operatorname{Ln} \theta}{\partial \operatorname{Ln} b}=\frac{f\left(w^{r}\right)}{1-F\left(w^{r}\right)} \frac{b}{1+\theta / \rho}=-\frac{b}{\sigma w^{r}} \frac{x-w^{r}}{x-b} \\
& \frac{\partial \operatorname{Ln} \theta}{\partial \operatorname{Ln} \lambda}=1-\frac{f\left(w^{r}\right)}{1-F\left(w^{r}\right)} \frac{w^{r}-b}{1+\theta / \rho}=1-\frac{w^{r}-b}{\sigma w^{r}} \frac{x-w^{r}}{x-b}=\frac{\partial \operatorname{Ln} w^{r}}{\partial \operatorname{Ln} b}
\end{aligned}
$$

where $f($.$) is the density function of wage offers and \sigma$ is the standard deviation of the log of wage offers, which is in turn equal to $\left(\mathrm{x}-\mathrm{w}^{\mathrm{r}}\right) / \mathrm{x} .^{1}$

\section{Data and results}

The analysis in this paper is based on a unique survey of the economically inactive in Wales. The sample included individuals of working age - men aged 16-64 and women aged 16-59who were inactive (and non-students) living in contrasting areas of economic inactivity: Valley Areas previously dominated by coal mining and/or steel industries, and which now have the highest rates of economic inactivity; Urban Hotspots where pockets of high economic inactivity exist in wards of otherwise prosperous urban areas; and Cooler Areas where inactivity levels are close to the national average.

\footnotetext{
${ }^{1}$ Gorter and Gorter $(1993)$ show that $(\partial \operatorname{Ln} \theta / \partial \operatorname{Ln} \lambda)=\left(\partial \operatorname{Ln}^{r} / \partial \operatorname{Ln} b\right)$.
} 
Fieldwork was completed in early 2004 and produced a representative sample of 1293 individuals. Information relating to the lowest weekly wage needed to take a job $\left(\mathrm{w}^{\mathrm{r}}\right)$ and the weekly wage expected if employed (x), however, was only collected for individuals who either wanted a job now or at some time in the future - i.e. respondents deemed to be 'closer' to the labour market and therefore more likely to be amenable to policies designed to increase labour market participation. ${ }^{2}$ Information on weekly income from state benefits (b) was collected for all respondents. ${ }^{3}$

Data on $\mathrm{w}^{\mathrm{r}}, \mathrm{x}$, and $\mathrm{b}$ was available for 406 individuals. However, some observations were dropped if they did not satisfy the rationality condition: $\mathrm{b} \leq \mathrm{w}^{\mathrm{r}} \leq \mathrm{x}$ (see Lancaster and Chesher, 1983), which was applied to two different formats of the data to account for the fact that some respondents wanted to work full time while others, mostly women, wanted to work part time. First, using work-time information collected for each wage measure, the data was converted to a standard 40 hour working week. Second, the sample was restricted to those wanting full-time work only - 178 individuals. Applying the rationality condition to the data gave a sample of 342 individuals based on the standard working week data and 162 based on the full-time work data.

Elasticity estimates based on expressions (3) and (4), along with estimates of the standard deviation of the log offer wage distribution, are reported in Table 1 for various sub-groups i.e. by gender, geographical location, and labour market proximity. Part (a) of Table 1 refers to the results based on the standard work week data, while part (b) refers only to the results

\footnotetext{
${ }^{2}$ Although this group may not be as actively engaged in job search as the unemployed, their perceptions of the labour market likely to confront them are nevertheless of interest to policy makers.

${ }^{3}$ State benefits are defined net of universal child benefits.
} 
obtained for individuals who said they wanted to work full-time. All estimates in Table 1 are evaluated at the means of the data.

While there are differences in the elasticity estimates reported in parts (a) and (b) of Table 1, in the main they are quite small, and in most cases the results are qualitatively similar. For this reason, we concentrate on the standard work week results when highlighting the key findings.

Table 1 shows that values of the elasticity of reservation wages to state benefits fall within a narrow range for most of the groups analysed - from 0.087 to 0.117 . To put these figures in perspective, Table 1 also shows the effect that a 1 per cent increase in benefits has on the reservation wage of each group in monetary terms. Hence for the combined sample, a 1 per cent increase in benefits raises the reservation wage by $£ 0.24 .^{4}$ Elasticity estimates of this order of magnitude are similar to those found elsewhere in the UK for unemployed workers [see Lancaster and Chesher, 1983 (14 per cent) and Narendranathan and Nickell, 1985 (16 per cent)]. The economically inactive therefore seem to respond in similar ways to benefit increases as unemployed workers.

Compared to the benefit elasticity, the elasticity of reservation wages to the arrival rate is typically higher for each of the sub-groups considered in Table 1. Thus for the combined sample, a 1 per cent increase in the arrival rate increases the reservation wage from between $£ 0.23$ (Valleys) to $£ 0.42$ (Cooler regions and those who Want to Work Within the Next Year). While these elasticity estimates are similar to those found by Lancaster and Chesher (1983) for unemployed workers, they are typically larger in size, which probably reflects the

\footnotetext{
${ }^{4}$ The increase for a $£ 1$ increase in benefits is $£ 0.23$.
} 
greater influence a potential increase in demand can have on this group who have both poor skills and poor employment prospects. ${ }^{5}$

Finally, as expected, increasing benefits reduces the exit rate, with elasticity estimates ranging from -0.527 (Males) to -0.818 (Valleys). Differences in the exit elasticity are largely accounted for by differences in the estimates of the variance parameter $(\sigma)$, which tend to be

quite small. Interestingly however, $\sigma$ is largest for those individuals who might be considered more proximate to the labour market, which suggests either that these individuals are able to choose from a wider range of job opportunities or that they are better informed about potential labour market opportunities.

\section{Conclusion}

The economically inactive, and particularly those indicating a desire to work, are increasingly attracting the interest of policy makers in Europe who seek to increase participation and employment rates. For the first time, and using unique survey data, the present analysis calculates estimates of the elasticity of the reservation wage and exit probability with respect to state benefits and the arrival rate of job offers for this group. The results suggest that changes in benefits, particularly incapacity benefits, could have an important part to play in meeting an 80 per cent employment rate target by 2010 .

\footnotetext{
${ }^{5}$ Almost 80 per cent of respondents had no formal qualifications.
} 


\section{References}

Department of Work and Pensions, 2005, Department of Work and Pensions Five Year Strategy: Opportunity and Security Throughout Life, HMSO.

Gorter, D. and C. Gorter, 1993, The relationship between unemployment benefits, reservation wage and search duration, Oxford Bulletin of Economics and Statistics 55, 199-214.

Mortensen, D., 1986, Job search and labor market analysis, in: O. Ashenfelter and R. Layard, eds., Handbook of labor economics, Vol.2 (North-Holland, Amsterdam) 849-916.

Lancaster, T. and A. Chesher, 1983, An econometric analysis of reservation wages, Econometrica 51, 1661-1676.

Narendranathan, W. and S. Nickell, 1985, Modelling the process of job search, Journal of Econometrics 28, 155-169.

Schweitzer, M., 2003, Ready willing and able? Measuring labour market availability in the UK, Working paper No. 186, Bank of England. 
Table 1: Elasticity Estimates Based on the Means of the Data

\begin{tabular}{|c|c|c|c|c|c|c|c|c|}
\hline \multirow[t]{2}{*}{ Part (a) } & \multicolumn{8}{|c|}{ Standard Work Week (40 hours) } \\
\hline & All & Male & Female & Valleys & $\begin{array}{c}\text { Urban } \\
\text { Hotspots }\end{array}$ & $\begin{array}{l}\text { Other } \\
\text { 'Cooler' } \\
\text { Areas }\end{array}$ & $\begin{array}{c}\text { Want to } \\
\text { Work Within } \\
\text { the Next } \\
\text { Year }\end{array}$ & $\begin{array}{c}\text { Wants to } \\
\text { Work But in } \\
\text { a Year or } \\
\text { More }\end{array}$ \\
\hline$\frac{\partial \operatorname{Ln} w^{r}}{\partial \operatorname{Ln} b}=\frac{\partial \operatorname{Ln} \theta}{\partial \operatorname{Ln} \lambda}$ & $\begin{array}{c}0.101 \\
(£ 0.24)\end{array}$ & $\begin{array}{c}0.095 \\
(£ 0.23)\end{array}$ & $\begin{array}{c}0.102 \\
(£ 0.24)\end{array}$ & $\begin{array}{c}0.087 \\
(£ 0.20)\end{array}$ & $\begin{array}{c}0.106 \\
(£ 0.23)\end{array}$ & $\begin{array}{c}0.103 \\
(£ 0.26)\end{array}$ & $\begin{array}{c}0.117 \\
(£ 0.27)\end{array}$ & $\begin{array}{c}0.089 \\
(£ 0.22)\end{array}$ \\
\hline$\frac{\partial \operatorname{Ln} w^{r}}{\partial \operatorname{Ln} \lambda}$ & $\begin{array}{c}0.132 \\
{[£ 0.31]}\end{array}$ & $\begin{array}{c}0.162 \\
{[£ 0.39]}\end{array}$ & $\begin{array}{c}0.121 \\
{[£ 0.29]}\end{array}$ & $\begin{array}{c}0.097 \\
{[£ 0.23]}\end{array}$ & $\begin{array}{c}0.127 \\
{[£ 0.28]}\end{array}$ & $\begin{array}{c}0.166 \\
{[£ 0.42]}\end{array}$ & $\begin{array}{c}0.184 \\
{[£ 0.42]}\end{array}$ & $\begin{array}{c}0.109 \\
{[£ 0.26]}\end{array}$ \\
\hline$\frac{\partial \operatorname{Ln} \theta}{\partial \operatorname{Ln} b}$ & -0.688 & -0.527 & -0.755 & -0.818 & -0.745 & -0.557 & -0.563 & -0.748 \\
\hline$\sigma$ & 0.147 & 0.179 & 0.135 & 0.107 & 0.142 & 0.185 & 0.209 & 0.119 \\
\hline $\mathrm{N}$ & 342 & 89 & 253 & 130 & 86 & 126 & 103 & 239 \\
\hline Part (b) & \multicolumn{8}{|c|}{ Full-time } \\
\hline$\frac{\partial \operatorname{Ln} w^{r}}{\partial \operatorname{Ln} b}=\frac{\partial \operatorname{Ln} \theta}{\partial \operatorname{Ln} \lambda}$ & $\begin{array}{c}0.107 \\
(£ 0.24)\end{array}$ & $\begin{array}{c}0.099 \\
(£ 0.23)\end{array}$ & $\begin{array}{c}0.114 \\
(£ 0.24)\end{array}$ & $\begin{array}{c}0.098 \\
(£ 0.20)\end{array}$ & $\begin{array}{c}0.122 \\
(£ 0.26)\end{array}$ & $\begin{array}{c}0.102 \\
(£ 0.26)\end{array}$ & $\begin{array}{l}0.100 \\
(£ 0.21)\end{array}$ & $\begin{array}{c}0.110 \\
(£ 0.26)\end{array}$ \\
\hline$\frac{\partial \operatorname{Ln} \theta}{\partial \operatorname{Ln} b}$ & -0.659 & -0.533 & -0.909 & -0.818 & -0.733 & -0.521 & -0.540 & -0.724 \\
\hline$\sigma$ & 0.163 & 0.186 & 0.126 & 0.120 & 0.167 & 0.196 & 0.186 & 0.152 \\
\hline $\mathrm{N}$ & 162 & 94 & 68 & 66 & 33 & 63 & 56 & 106 \\
\hline
\end{tabular}

Notes: Figures in round brackets show the increase in reservation wages to a 1 per cent increase in benefits in monetary terms. Figures in square brackets show the corresponding increase in the reservation wage for a 1 per cent increase in the arrival rate. 